Loyal Subjects 



\section{Loyal Subjects}

Bonds of Nation, Race, and Allegiance in Nineteenth-Century America

Elizabeth Duquette

Rutgers University Press

NEW BRUNSWICK, NEW JERSEY, AND LONDON 
Copyright () 2010 by Elizabeth Duquette

All rights reserved

No part of this book may be reproduced or utilized in any form or by any means, electronic or mechanical, or by any information storage and retrieval system, without written permission from the publisher. Please contact Rutgers University Press, 100 Joyce Kilmer Avenue, Piscataway, NJ 08854-8099. The only exception to this prohibition is "fair use" as defined by U.S. copyright law.

Visit our Web site: http://rutgerspress.rutgers.edu

Manufactured in the United States of America

LIBRARY OF CONGRESS CATALOGING-IN-PUBLICATION DATA

Duquette, Elizabeth, 1963-

Loyal subjects : bonds of nation, race, and allegiance in nineteenth-century America / Elizabeth Duquette.

p. cm. - (American literatures initiative)

Includes bibliographical references and index.

ISBN 978-0-8135-4780-o (hardcover : alk. paper)

ISBN 978-0-8135-4781-7 (pbk. : alk. paper)

1. American literature-19th century-History and criticism. 2. United States-History-Civil War, 1861-1865-Literature and the war. 3. National characteristics, American, in literature. 4. Loyalty in literature. 5. Allegiance in literature. 6. Nationalism in literature. 7. Nationalism and literature-United States-History-19th century. I. Title.

PS217.N38D87 2010

$810.9^{\prime} 358735-\mathrm{dc} 22$

2009043151

A British Cataloging-in-Publication record for this book is available from the British Library.

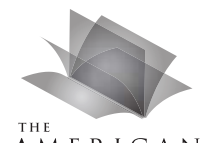

A M E R I C A N LITERATURES I N I T I A T I VE
A book in the American Literatures Initiative (ALI), a collaborative publishing project of NYU Press, Fordham University Press, Rutgers University Press, Temple University Press, and the University of Virginia Press. The Initiative is supported by The Andrew W. Mellon Foundation. For more information, please visit www.americanliteratures.org. 
In memory of my mother, Marie H. Duquette 
